\title{
EDITORS' INTRODUCTION Alcohol and violence: Relationships, causality, and policy
}

BY CLAIRE WILKINSON AND ROBIN ROOM

The articles in this issue of Contemporary Drug Problems were revised from papers presented and discussed at an international research conference held in Melbourne, Australia, on 15-18 March, 2010. The conference, funded by the Alcohol Education \& Rehabilitation Foundation (AERF) and VicHealth, was hosted by the AER Centre for Alcohol Policy Research, Turning Point Alcohol \& Drug Centre, a unit of Eastern Health, and was a thematic meeting of the Kettil Bruun Society for Social and Epidemiological Research on Alcohol (KBS).

This was not the first KBS thematic meeting on alcohol and violence. A conference on Intoxication and Aggressive Behavior in Toronto in October, 1996, pursued a related theme, resulting in a previous thematic issue of Contemporary Drug Problems (Graham, 1997). That conference was held in the wake of a major Canadian policy fight over alcohol intoxication as a legal excuse for sexual violence, a controversy which had resulted in another thematic issue of this journal (Bondy, 1996). An earlier conference in Berkeley, California, had also pursued the theme in reviewing social science research streams on alcohol and disinhibition (Room \& Collins, 1983). 
The Melbourne conference brought together both established researchers and a younger generation of scholars and graduate students, with a program broadly structured around four themes:

- Alcohol and violence in the night-time economy and the policy response

- Aggregate and epidemiological studies

- Alcohol and intimate and gendered violence

- Community and contextual intervention studies to reduce alcohol-related violence

The articles in this issue predominately focus on the epidemiology of alcohol and violence, but with reference also to community and contextual interventions and the policy response. A thematic edition of Drug \& Alcohol Review includes further articles revised from research presented at the conference.*

The paper by Lightowlers explores the association between binge drinking and assault among young people in England and Wales, using data from two waves of a crime and justice panel survey. Lightowlers develops models exploring the temporal association of binge drinking in the year prior to committing an assault and explores the potential modifying effect of gender. It is current drinking-pattern behavior that has a stronger relationship to assault than the drinking pattern reported in the previous year. These results tend to point policies and programs to prevent alcohol-related violence toward strategies aimed at affecting drinking or its contexts in the present moment, rather than lifecourse interventions aiming for longer-term effects.

A contribution towards developing such strategies directed at the drinking occasion is made in the article by Greenfield et al. Using data from a large American general population survey, Greenfield et al. examine the influence of the setting where people drink the most, and of the maximum amount drunk there, on both assaults and being a victim of an assault involving alcohol. They find that being involved in alcohol-related fights is significantly predicted by measures of heavy drinking, even after other factors, including an impulsive/sensation-seeking personality measure, are con- 
trolled. Drinking in bars is a context particularly related to alcohol-related fights, though the relationship becomes nonsignificant when amount of drinking is controlled.

Hope and Mongan examine alcohol-related violence in Ireland. They use surveys of adult and student populations to examine the occurrence of both assaults and victimization, and factors associated with experiencing these problems. Their findings are put into a context of a sharp rise in alcohol-related violence in Ireland in the years prior to the surveys, which they interpret in terms of niche theory (Gruenewald, Remer, \& Treno, 2009)—a greater number of venues, in encouraging differentiation of drinkers into subpopulations, provide attractive venues for more problematic drinking. The need for a national alcohol policy to counter such developments is emphasized.

Using a general population survey of adults in Ontario, Canada, the paper by Wells, Giesbrecht and colleagues examines the relationship of drinking pattern with alcohol involvement in aggression as well as the severity level of that aggression (verbal or physical). Controlling for other factors, they find that measures of hazardous drinking are related to alcohol-related aggression, but not to aggression without alcohol involved. Again, the results tend to argue for a focus for preventive efforts on aspects of the drinking situation, rather than predisposing factors such as personality dimensions.

Focusing on drinking in bars, the context Greenfield et al. find to be most associated with alcohol-related violence, Wells, Graham and colleagues explore the expected effects of alcohol on aggression in that context, using a new inventory of expectancy items focusing on the bar setting. They explore variability in these expectancy effects across three hypothetical examples of provoking situations which may occur in a barroom setting. The usefulness of the tool is evaluated. In focusing on context-specific expectancies, the article charts a path forward in developing research on alcohol expectancies in a promising direction for preventive interventions. 
An important aspect of epidemiological research on alcohol and violence is the analysis of register series on alcohol consumption levels and indicators of violence, including statistics on assaults and homicides (Room \& Rossow, 2001). But analyses need to take account of the meaning and implications of the underlying data. Österberg and Karlsson consider these issues in examining trends in violence in the Nordic countries between 1960-2000, where in general alcohol consumption has been on the rise. The article describes trends in police data on both assaults and homicides, and considers the relationship of these trends to trends in levels of alcohol consumption. Discussing the reasons that homicide data are a more reliable indicator than assault data, the authors suggest that violence has not been increasing faster than alcohol consumption over the time period studied, contrary to what the assault data on their own would indicate.

The articles in this edition illustrate a range of social and epidemiological approaches to examining the relation between alcohol and violence. Examining individual, situational, and contextual factors and their interplay in relation to alcohol and violence, the work speaks to a range of ways to focus initiatives to reduce rates of alcohol-related violence.

The editors would like to thank all the reviewers who contributed to the articles in this edition.

As we finished this introduction, the sad news came of the death of Kai Pernanen. Kai made fundamental contributions to thinking about and analysis of the relations between alcohol and violence, starting with his landmark piece "Alcohol and Crimes of Violence" (Pernanen, 1976) and including his book Alcohol in Human Violence (Pernanen, 1991). This issue is dedicated to his memory. 
Note *The issue of Drug and Alcohol Review 30(5) includes the following articles:

Abbey, A. Alcohol's role in sexual violence perpetration: Theoretical explanations, existing evidence, and future directions.

Bellis, M., \& Hughes, K. Getting drunk safely? Nightlife policy in the UK and its public health consequences.

Graham, K., Bernards, S., Wells, S., Osgood, D., Abbey, A., Felson, R., et al. Behavioural indicators of motives for barroom aggression: Implications for preventing bar violence.

Kerr, W., Subbaraman, M., \& Ye, Y. Per capita alcohol consumption and suicide mortality in a panel of U.S. states from 1950 to 2002.

Liang, T., \& Chikritzhs, W. Revealing the link between licensed outlets and violence: Counting venues versus measuring alcohol availability.

Livingston, M. Alcohol outlet density and harm: Comparing the impacts on violence and chronic harms.

Miller, P., Sønderlund, A., Coomber, K., Palmer, D., Tindall, J., Gillham, K., et al. Do community interventions targeting licensed venues reduce alcohol-related Emergency Department presentations?

Norström, T. Alcohol and homicide in the United States-is the link dependent on wetness?

Parker R., Williams, K., McCaffree, K., Asencio, E., Browne, A., Strom, $\mathrm{K}$., et al. The relationship between retail availability and youth homicide: Alcohol and youth violence in the 100 largest U.S. cities 1984-2006.

Parker, R., McCaffree, K., \& Skiles, D.I. The impact of retail practices on violence: The case of single serve alcohol beverage containers.

Peérez-Diaz, C., \& Hureé, M.-S. Heavy drinking and the disposition of intimate partner violence cases in French courts.

Ramstedt, M. Population drinking and homicide in Australia-A time series analysis of the period 1911-2003.

\section{References}

Bondy, S. (1996). Editor's introduction: Self-induced intoxication as a defence in the Criminal Code of Canada: Issues and discussion around Daviault v. R. Contemporary Drug Problems, 23(4), 571-582.

Graham, K. (1997). Editor's introduction: Intoxication and aggressive behaviour: Understanding and preventing alcohol-related violence. Contemporary Drug Problems, 24(4), 621-624. 
Gruenewald, P., Remer, L.G., \& Treno, A.J. (2009). Alcohol outlets, crime and disorder in the United States of America. In P. Hadfield (Ed.), Nightlife and crime: Social order and governance in international perspective (pp. 19-50). Oxford: Oxford University Press.

Pernanen, K. (1976). Alcohol and crimes of violence. In B.K. Kissin \& H. Begleiter (Eds.), The biology of alcoholism: Social aspects of alcoholism, (Vol. 4, pp. 351-444). New York: Plenum.

Pernanen, K. (1991). Alcohol in Human Violence. London: Guilford Press.

Room, R., \& Collins, G. (Eds.). (1983). Alcohol and disinhibition: The nature and meaning of the link (DHHS Publication No. ADM 831246). Washington, D.C.: U.S. Government Printing Office, .

Room, R., \& Rossow, I. (2001). The share of violence attributable to drinking. Journal of Substance Use, 6, 218-228. 
Copyright of Contemporary Drug Problems is the property of Federal Legal Publications Inc. and its content may not be copied or emailed to multiple sites or posted to a listserv without the copyright holder's express written permission. However, users may print, download, or email articles for individual use. 